ISSN 2078-6441. Вісник Львівського університету. Серія географічна. 2013. Випуск 44. С. 8-16. Visnyk of the Lviv University. Series Geography. 2013. Issue 44. P. 8-16.

631.4

\author{
вятосл в люк, юдмил оротинцев \\ ціон льний н уковий центр \\ “нститут грунтозн вств $m$ грохімї імені . . околовського”, \\ вул. йковськ , 4, 61024, м. рків, кр їн
}

озкрито н прями тр нсформ ції вл стивостей чорноземних грунтів під впливом сільськогоспод рського використ ння $\mathrm{T}$ зрошення. оведено, що для зб л нсов ного $\mathrm{T}$ ст лого землекористув ння необхідною скл довою є регл мент ція нтропогенного н в нТ ження н грунти н $з$ с д х визн чення прийнятного екологічного ризику їхньої дегр д ції з ур хув нням стійкості грунту до нтропогенного н в нт ження. грунти.

лючові слов : вл стивості грунту, грунт, гумус, зрошення, стійкість грунту, чорноземні

рунти є н йціннішим н ціон льним 6 г тством і посід ють визн чне місце в житті т діяльності людини. контексті біосферної п р дигми природокористув ння грунтовий покрив розгляд ють як основний (с мостійний) природний ресурс, нез мінний компонент біосфери і природного середовищ, який відігр є в жливі функції: продуктивну, соці льно-духовну, екологічну т ін. ме грунт м, як с мостійним природно-історичним різном нітним утворенням, кожне з яких м є свою морфологію, скл д, вл стивості, режими функціонув ння, прит м нН зд тність з безпечув ти рослини біогенними елемент ми, водою й іншими умов ми, необхідними для їхнього норм льного росту й розвитку.

кр їн є однією 3 н йбільш освоєних з сільськогоспод рського погляду держ в світу. лизько $70 \%$ сільськогоспод рських угідь розор но і з йнято природнонтропогенними л ндш фт ми, структур яких екологічно незб л нсов н . ід впливом трив лого сільськогоспод рського використ ння, екологічно незб л нсов ного землеробств, техногенних н в нт жень відбув ється тр нсформ ція вл стивостей грунтів т змін еволюційної н прямленості грунтових процесів і режимів, що потребує моніторингових спостережень, прийняття упр влінських рішень, норм тивного з безпечення охорони грунтів т регл мент ції нтропогенних н в нт жень 3 ур хув нням екологічного ризику т вл сне стійкості грунту до зовнішніх впливів для з безпечення ст лого землекористув ння.

б'єктом досліджень є чорноземні грунти кр їни. ослідження проводили в умов х моніторингових спостережень, польових дослідів 3 використ нням системного н лізу отрим них д них.

кр їні з г льн площ земель ст новить 60 млн г . лощ земель сільськогоспод рського призн чення - 43 млн г , площ ріллі - 32,5 млн г , тобто ступінь розор ності сільськогоспод рських угідь ст новить $80 \%$, сільськогоспод рського освоєння $-70 \%$ (див. рис. 1). д дмірне розширення ріллі, у тому числі н м лопродуктивних,

(C) люк ., оротинцев ., 2013 
3 пл вних грунт х призвело до порушення екологічно зб л нсов ного співвідношення сільськогоспод рських угідь, лісів і водоймищ, що зумовило несприятливі н слідки техногенного н в нт ження н екосферу.
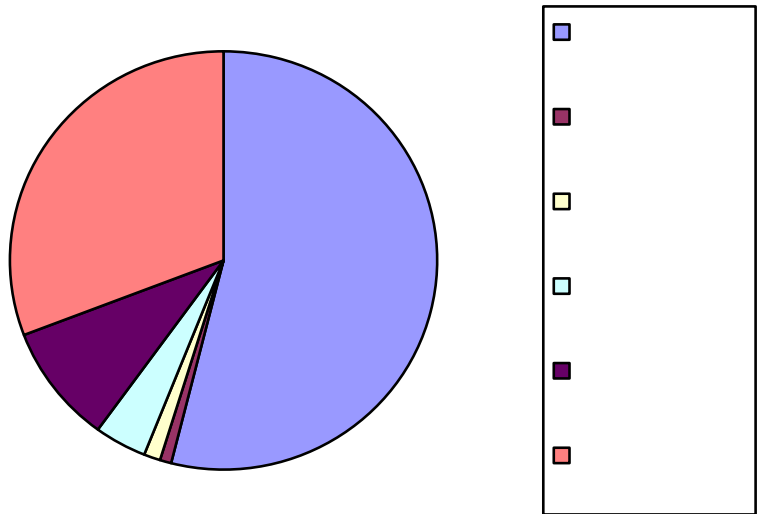

ис. 1. емельний фонд кр їни.

структурі грунтового покриву домінують грунти чорноземного типу, які з йм ють площу близько 27-28 млн г (65\% від з г льної площі) і є унік льними тіл ми природи 3 будовою, вл стивостями і потенційною родючістю. дн к під впливом інтенсивного ненормов ного нтропогенного н в нт ження в грунт х розвив ються т кі дегр д ційні процеси, як дегуміфік ція, зрост ння дефіцитності 6 л нсу рухомих поживних речовин, підкислення, переущільнення, ерозійне зменшення потужності верхнього ш ру грунту, вторинне з солення й осолонцюв ння зрошув них чорноземних грунтів $[1,2]$.

1986-1990 pp. в кр їні був досягнутий н йвищий рівень ресурсного з безпечення, що д ло змогу з безпечити бездефіцитний б л нс орг нічної речовини і поживних елементів [3]. дн к з 1991 р. посилилися нег тивні тенденції в зміні вл стивостей грунтів ун слідок м йже повного припинення фін нсув ння держ вних, регіон льних і місцевих прогр м охорони земель. бсяги хімічної меліор ції, виробництв і з стосув ння орг нічних т мінер льних добрив скоротилися в чотири-п'ять, то і в десять $\mathrm{p}$ зів, що ст ло причиною дефіцитного б л нсу як 3 вмістом орг нічної речовини (від 100-250 до 30-70 кг/г ) з ур хув нням з орюв ння в грунт пожнивних з лишків (див. рис. 2), т к і 3 вмістом поживних елементів (від 70-80 до 30 кг/г NPK) (див. т блицю).

лощі дегр дов них грунтів в кр їні, з д ними різних джерел, колив ються від 5-6 до 10 млн г . ниження продуктивності основних сільськогоспод рських культур є в меж х від 10-20 до 40-50\% з лежно від ступеня дегр д ції. оловною причиною дегр д ції грунтів є недост тній рівень держ вного упр вління земельними (грунтовими) ресурс ми, відсутність держ вного контролю 3 ре ліз цією прогр м 3 охорони грунтового покриву як н ціон льного н дб ння.

умусний ст н чорноземних грунтів визн чений, головно, структурою посівних площ, н явністю в ній б г торічних бобових тр в, рівнем 3 стосув ння добрив і терміном сільськогоспод рського використ ння грунтів. ин мік змін вмісту гумусу в чорноземних грунт х з 100-літній період свідчить, що після розорюв ння (освоєння) цілини фіксують зниження в дв -три р зи обсягу н дходження в грунт біом си, змінюється співвідношення хімічних елементів, скорочується потужність кореневміс- 
ної зони і посилюються мінер ліз ційні процеси [5]. тже, простежується тенденція щодо зниження вмісту гумусу в грунт х.

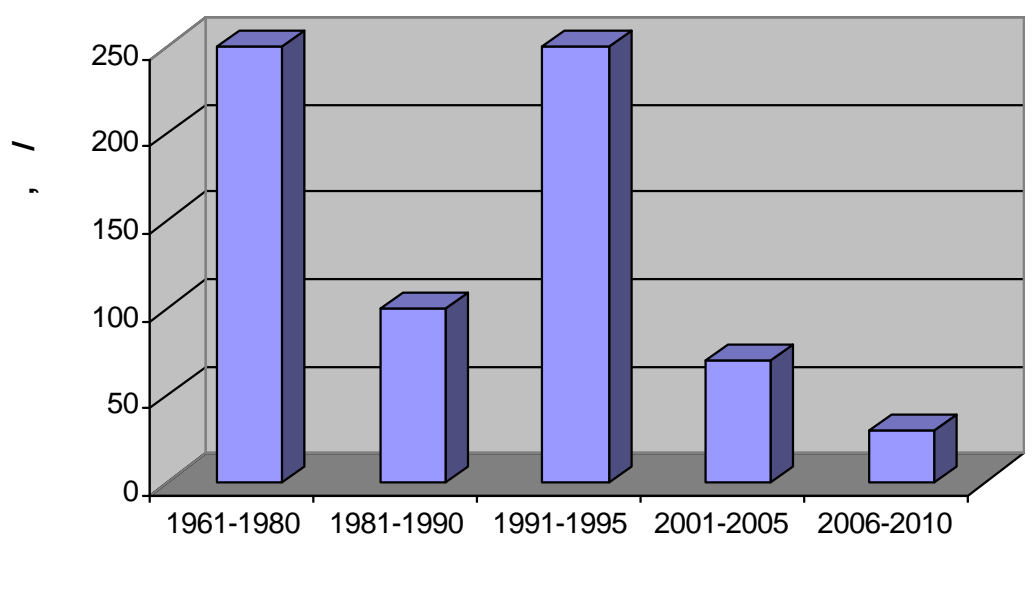

ис. 2. ин мік 6 л нсу гумусу в грунт х кр їни [4].

езульт ти ст ціон рних спостережень свідч ть, що втр ти гумусу в р зі різного господ рського використ ння грунтів ст новлять від 15-20 до $30 \%$. окрем , 3 д ними . егтярьов [6], у розор них і перелогових чорнозем х типових “ их йлівської цілини" порівняно з цілиною простежено зниження вмісту гумусу н 13-20\%, особливо н в рі нті з ріллею (65 і 120 років використ ння).

ин мік б л нсу поживних речовин у землеробстві кр їни [4]

\begin{tabular}{|c|c|c|c|c|}
\hline т тті б л нсу, кг/Г & 30T & ocфор ( $\left(\begin{array}{ll}2 & 5\end{array}\right)$ & лій ( 2 ) & зом (NPK) \\
\hline \multicolumn{5}{|c|}{$1986-1990 \mathrm{pp}}$. \\
\hline дходження & 91,0 & 52,5 & 79,5 & 223,0 \\
\hline инесення & 95,0 & 31,9 & 92,0 & 218,9 \\
\hline л $\mathrm{Hc}$ & $-4,0$ & 20,6 & $-12,5$ & 4,1 \\
\hline \multicolumn{5}{|c|}{ 1996-2000 pp. } \\
\hline дходження & 26,0 & 10,4 & 15,3 & 51,7 \\
\hline инесення & 56,5 & 18,2 & 53,7 & 128,4 \\
\hline л нс & $-30,5$ & $-7,8$ & $-38,4$ & $-76,7$ \\
\hline \multicolumn{5}{|c|}{ 2001-2005 pp. } \\
\hline дходження & 36,5 & 9,0 & 18,7 & 64,2 \\
\hline инесення & 69,3 & 49,2 & 43,0 & 131,5 \\
\hline л нс & $-32,8$ & $-10,2$ & $-24,3$ & $-67,3$ \\
\hline \multicolumn{5}{|c|}{ 2006-2010 pp. } \\
\hline дходження & 50,4 & 11,1 & 20,5 & 82,1 \\
\hline инесення & 67,5 & 19,7 & 29,6 & 116,8 \\
\hline л нс & $-17,0$ & $-8,6$ & $-9,1$ & $-34,7$ \\
\hline
\end{tabular}

рив ліше використ ння грунтів у польових сівозмін х (пон д 120 років) не призводить до суттєвих змін вмісту гумусу. період від 70-80 до 100 років процеси мінер ліз ції гумусу компенсов ні процес ми гумусоутворення й вміст гумусу 
ст білізується [6]. емпи мінер ліз ції і гумусон гром дження з свідчують, що в перші 12 років сільськогоспод рського використ ння інтенсивність утр т гумусу ст новить у середньому $0,09 \%$ з рік, потім вон знижується м йже в дв р зи і в н ступні 40-45 років колив ється в меж х 0,05-0,04\% 3 рік. ерез 65 років використ ння інтенсивність утр т ст новить усього 0,01 \% (з г льні втр ти н рівні 30-36 \%).

уз г льненими д ними, відносні втр ти гумусу з 120-річний період після . окуч єв досягли $22 \%$ у ісостепу, 20 - у теповій і пон д $19 \%$ у оліській зоні кр їни [3]. д ними грохімічної п спортиз ції земель сільськогоспод рського призн чення, протягом ост нніх п’яти турів (1986-2010) вміст гумусу зменшився н $0,5 \%$ в бсолютних величин $\mathrm{x}$, особливо помітно між п'ятим і шостим туром $(0,37 \%)$, коли поч ли різко зменшув ти з стосув ння орг нічних добрив.

дним із потужних чинників, що вплив $є$ н спрямов ність, швидкість розвитку 6 г тьох грунтових процесів і тр нсформ цію грунтів, є зрошення. прямов ність, періодичність і швидкість перетворень визн чені якістю поливних вод, поч тковим ст ном грунтів і ступенем природної дренов ності території, технологією зрошення й культурою землеробств (рис. 3).

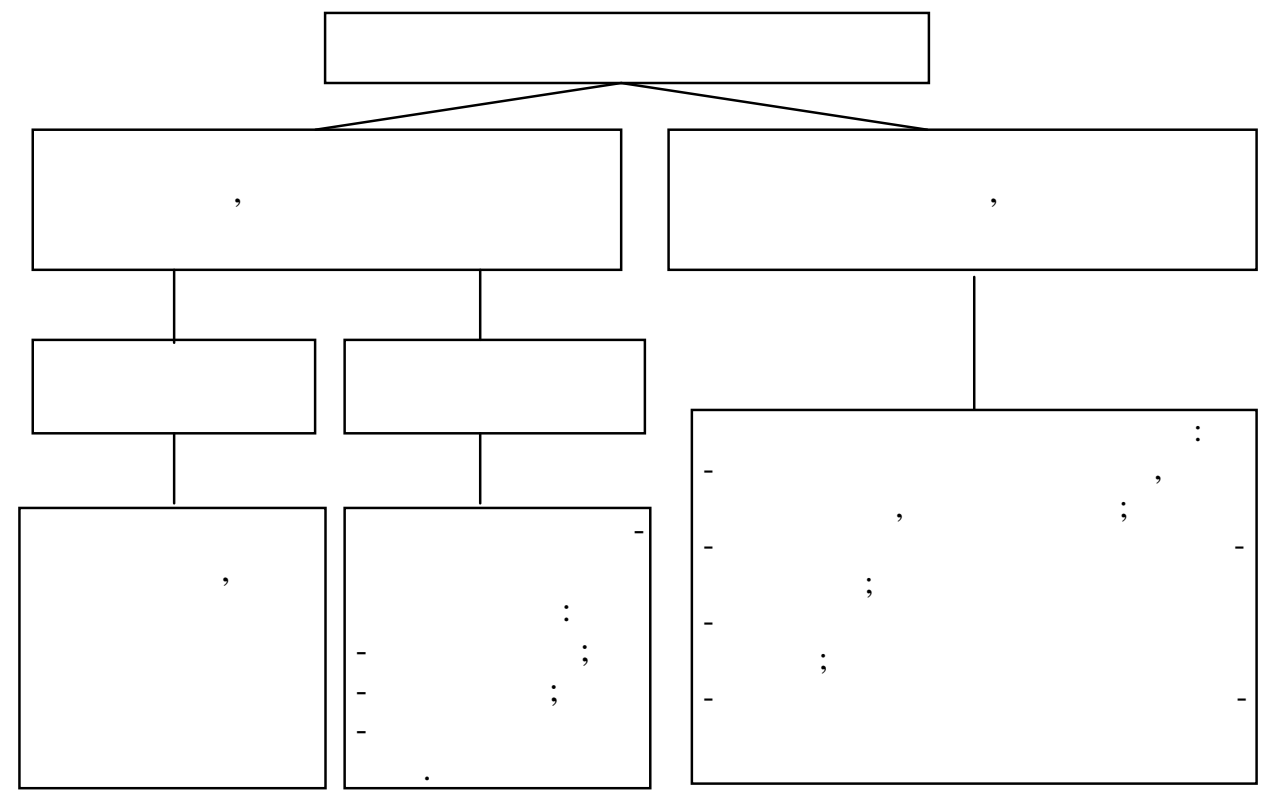

ис. 3. хем еволюції зрошув них грунтів.

л сними б г торічними дослідженнями в зон х івнічнокримського, ховського, нгулецького к н лів і н зрошув льних систем х онецької обл сті визн чено низку 3 кономірностей еволюції чорноземних і к шт нових грунтів, зрошув них вод ми різної якості, т кож розроблено комплексні з ходи з керув ння їхнім екологогромеліор тивним ст ном т підвищення родючості [7].

p зі використ ння для зрошення вод першого кл су (прид тних для зрошення 3 грономічними й екологічними критеріями) 3 високої культури землеробств, у 
сівозмін х з б г торічними бобовими тр в ми, з з стосув нням н уково обгрунтов ної системи удобрення відбув ється окультурення грунтів, підвищення їхньої природної т ефективної родючості з вдяки ліпшій зволоженості, збільшенню вмісту поживних м кро- і мікроелементів, дод тного б л нсу гумусу, підвищенню з г льної біогенності. цьому р зі з вдяки зрошенню формуються високопродуктивні гроценози з визн ченими п р метр ми вл стивостей грунтів, продуктивність яких вищ від незрошув них н логів у дв -чотири до семи-восьми р зів з лежно від вирощув них культур [8].

зрошення вод ми першого кл су в сівозмін х без б г торічних бобових тр в (у тім числі овочевих), з низької культури землеробств т недост тнього ресурсного з безпечення відбув ються дегуміфік ція, ущільнення, знеструктурення т злитиз ція грунтів, одн к їхня продуктивність зберіг ється вищою, ніж н незрошув них н лог х.

умов х зрошення вод ми другого кл су (обмежено прид тні для зрошення) $\mathrm{i}$, особливо, третього кл су (неприд тні для зрошення з грономічними й екологічними критеріями) розвив ються дегр д ційні процеси - 3 солення, осолонцюв ння, ущільнення, знеструктурення т злитиз ція, кіркоутворення, з бруднення. т ких умов н віть з стосув ння комплексу громеліор тивних з ходів д $є$ змогу лише обмежити, стрим ти, посл бити прояв цих процесів, проте цілком не усув є.

г льною тенденцією еволюції вл стивостей грунтів після припинення їхнього зрошення, що простежується в нинішніх соці льно-економічних умов х, є відновлення п р метрів, х р ктерних для їхніх незрошув них н логів. видкість т інтенсивність цих процесів з лежить, передусім, від вл стивостей зрошув них грунтів, якості води т природно-клім тичних умов території [8].

ля збереження, охорони грунтів і зб л нсов ного землекористув ння необхідн регл мент ція нтропогенного н в нТ ження н грунти н підст ві визн чення прийнятного екологічного ризику їхньої дегр д ції, як повинн з безпечити рівнов гу між нтропогенним впливом т зд тністю грунтів до с мовідновлення, збереження своїх біогеоценотичних функцій т х р ктерних п р метрів і вл стивостей з різном нітних фізичних, хімічних і біологічних впливів ун слідок визн чення гр ничних зн чень потенці лу стійкості. огляду н це розроблено низку документів: “ онцепцію екологічного нормув ння допустимого нтропогенного н в нТ ження н грунтовий покрив” [9], “ онцепцію інтегров ного упр вління екологічним ризиком дегр д ції грунтів” [10] т підготовлено рекоменд ції “ цінк стійкості грол ндш фтів і грунтів до впливу зрошення".

кологічно безпечне землекористув ння, що грунтується, перш 3 все, н зд тності грунту зберіг ти свої екологічні функції 3 зовнішнього впливу нтропогенних чинників, є невіддільною скл довою ст лого розвитку. ідповідно до кону кр їни “ ро охорону земель”, для г р нтув ння екологічної т с ніт рно-гігієнічної безпеки гром дян потрібно регл ментув ти господ рську діяльність, визн чивши вимоги до якості землі, родючості грунтів, рівня їхнього господ рського освоєння т допустимого нтропогенного н в нт ження.

тр тегія р ціон льного землекористув ння передб ч $є$ узгодження розвитку гр рного природно-ресурсного потенці лу з пріоритет ми соці льно-економічної політики. $\quad$ с д х позитивного міжн родного досвіду т досягнень н укового пізн ння $з$ кономірностей еволюції природних систем методологічною основою екологічної стр тегії у г лузі землекористув ння повинен ст ти системний підхід, спрямов ний н мініміз цію ризику дегр д ції грунтів (земель) [10]. 
сновною метою розроблення “ онцепції інтегров ного упр вління екологічним ризиком дегр д ції грунтів" є формув ння н укових основ стр тегії екологічно безпечного використ ння т ефективної охорони земельних ресурсів кр їни як основи зб л нсов ного розвитку, т кож визн чення пріоритетних н прямів, підходів т 3 вд нь щодо з безпечення мініміз ції екологічного ризику дегр д ції грунтового покриву для з побіг ння погіршенню екологічного ст ну земельних ресурсів кр їни.

р хув ння екологічних ризиків під ч с упр вління земельними ресурс ми сприятиме призупиненню дегр д ції грунтового покриву т підвищенню ефективності охорони грунтів як унік льного об'єкт довкілля.

нтегров не упр вління екологічним ризиком дегр д ції грунтів є основою формув ння нового підходу, з снов ного н стр тегії упр вління екологічним ризиком, згідно 3 яким розмір допустимого рівня нтропогенного н в нТ ження н грунтовий покрив треб визн ч ти н підст ві розр хунку прийнятного екологічного ризику його дегр д ції.

изн чити кількісні зн чення екологічних норм тивів, т кож розмір прийнятного екологічного ризику дегр д ції грунтів неможливо без х р ктеристики їхньої стійкості до конкретного виду нтропогенного впливу. ід стійкості грунту й грол ндш фту 3 г лом зн чно з лежить їхній екологічний ст н, ступінь перетворення вн слідок господ рської діяльності, т кож зд тність трив лий ч с виконув ти свої соці льноекономічні й екологічні функції.

кту льність досліджень з цієї проблем тики зумовлен пр ктичною необхідністю 3 стосув ння оціненого потенці лу стійкості грунтів і л ндш фтів 3 г лом як 6 зового м тері лу для прогнозув ння змін у них, нормув ння нтропогенних н в нт жень, p ціон ліз ції природокористув ння, пл нув ння зб л нсов ного еколого-соці льноекономічного розвитку регіонів (особливо техногенно н в нт жених, н прикл д, онб су). цінюв ння т вр хув ння стійкості грунтів і грол ндш фтів д $є$ змогу попередити погіршення еколого- громеліор тивного ст ну земель, розробити диференційов ний комплекс з ходів з охорони й підвищення родючості грунтів з ур хув нням вл стивостей грунту.

д ними б г торічних досліджень ми з пропонув ли експертну десятиб льну оцінку стійкості грол ндш фтів т їхніх основних компонентів (клім ту, рельєфу, гідрогеологічних умов, флори, ф уни т біотичної скл дової) до впливу зрошення, т кож розробили методику експеримент льного визн чення п р метрів стійкості грунтів т н д ли експертну оцінку їхньої стійкості до іриг ційного з солення, осолонцюв ння й з бруднення в жкими мет л ми.

тійкість грунтів, як і л ндш фтів 3 г лом, не є простою сумою стійкості окремих їхніх компонентів. он з лежить від стійкості її скл дових, т кож від стійкості систем вищого рівня - грол ндш фтів т їхніх компонентів. н шу думку, зрошув ні л ндш фти і грунти, м ють бути стійкими до нег тивного впливу зрошення і нестійкими у н прямі еволюції їх до більш біопродуктивних і екологобезпечних для н вколишнього природного середовищ і людств .

підст ві н лізу д них 6 г торічних досліджень 3 пропонов но т ку експертну оцінку стійкості грунтів до іриг ційного з солення. йстійкішими $є$ втоморфні (з рівнем підгрунтових вод більше 5 м від поверхні), добре дренов ні, піщ ні т супіщ ні грунти. тійкість їх оцінюють в 10-7 б лів. ередньостійкими є втоморфні (з рівнем підгрунтових вод більше 5 м) і н півгідроморфні (з рівнем підгрунтових вод 3-5 м) легко- і середньосуглинкові, недост тньо дренов ні грунти, які оцінюють у 7-4 6 лів. 
ідроморфні (з рівнем підгрунтових вод до 3 м), сл бко дренов ні, в жкосуглинкові і глинисті грунто-підгрунтя вв ж ють низькостійкими з оцінкою в 4-1 6 ли. стійкістю до іриг ційного осолонцюв ння (в 6 л х) грунти поділяють т к:

- $\quad$ йбільш стійкі - високобуферні грунти з вмістом у верхньому орному горизонті к рбон тів к льцію 3 пон д $5 \%$, умістом гумусу пон д $6 \%$, ємністю грунтовопоглин льного комплексу ( ) пон д 30 мекв/100 г, співвідношенням у грунтовому розчині термодин мічних потенці лів підлуження т осолонцюв ння $\left(\frac{\mathrm{p}-\mathrm{pNa}}{\mathrm{pNa}-0,5 \mathrm{pCa}}\right)$

до 3. тійкість т ких грунтів оцінюють у 10-7 б лів;

- середньостійкі - середньобуферні грунти з вмістом

3 2-5\%, умістом гумусу

3-6 \%, ємністю

$$
\text { 15-30 мекв/100 г } \frac{\mathrm{p}-\mathrm{pNa}}{\mathrm{pNa}-0,5 \mathrm{pCa}}-3-7 . \text { льн оцінк стійкості }
$$

т кої групи грунтів ст новить 7-4 б ли;

- низькостійкі - низькобуферні грунти з умістом

3 до $2 \%$, гумусу до $3 \%$, ємністю $\quad 15$ мекв/100 г, $\frac{\mathrm{p}-\mathrm{pNa}}{\mathrm{pNa}-0,5 \mathrm{pCa}}$ пон д 7. тійкість цієї групи грунтів оцінюють у 4-1 6 л.

одо з бруднення в жкими мет л ми в умов х зрошення, то, н н ш погляд, стійкішим до з бруднення можн вв ж ти грунто-підгрунтя легкого гр нулометричного скл ду з низькою поглин льною зд тністю і високими фільтр ційними вл стивостями, н логічно стійкості грунтів до з солення простими токсичними солями (хлорид ми, сульф т ми, к рбон т ми, нітр т ми, н трію, м гнію т ін.).

огляду н фізичні т фізико-хімічні вл стивості зрошув них грунтів н йстійкішим буде добре дренов ний піщ ний т супіщ ний грунт (10-7 б лів), середньостійким грунт легко- т середньосуглинкового гр нулометричного скл ду (7-4 б ли), н йменш стійким - в жкосуглинкового i глинистого гр нулометричного скл ду, пог но дренов ний грунт (4-1 б ли).

тже, під впливом довготрив лого сільськогоспод рського використ ння, зрошення земель вод ми різної якості бо вилучення земель зі зрошення фіксують еволюційні зміни н прямленості грунтових процесів і режимів, тр нсформ цію вл стивостей грунтів, що потребує проведення моніторингових спостережень. ля збереження, охорони грунтів і $3 б$ л нсов ного землекористув ння необхідн регл мент ція нтропогенного н в нт ження н грунти н 3 с д $\mathrm{x}$ визн чення прийнятного екологічного ризику їхньої дегр д ції т вр хув ння стійкості грунту до зовнішніх чинників.

\section{СПИСОК ВИКОРИСТАНОЇ ЛІТЕРАТУРИ}

1. едведев . . ониторинг почв кр ины / . . едведев. - ., 2012. - 535 с.

2. едведев . . егр д ція чорноземів, пї причини i шляхи упередження / . . едведев // осібник укр їнського хлібороб . - 2013. - . 92-94.

3. ціон льн доповідь про ст н родючості грунтів кр їни. - ., 2010. - 106 с. 
4. ришняк . . л нс гумусу і поживних речовин у грунт х кр їни / . . ришняк, . . люк, . . ісовий, . . ом рист // існик гр рної н уки. - № 1. - 2012. - . 28-32.

5. обровольский . . вопросу об истории и состоянии учения об орг ническом веществе почв. оль почв в биосфере / . . обровольский // руды н-т экологического почвоведения осковского госуд рственного университет . - ., 2012. ып. 12. - . .5-13.

6. егтярьов . . умус чорноземів ісостепу і тепу кр їни / . . егтярьов. ., 2011. $-358 \mathrm{c}$.

7. укові основи охорони т р ціон льного використ ння зрошув них земель кр їни / [з н у ук. ред. . . люк , . . ом щенк , . . т шук ]. - . : гр рн н ук, 2009.-620 с.

8. ов ленко . . укове обгрунтув ння розвитку зрошення земель в кр їні / . . ов ленко, . . ом щенко, . . люк // існик гр рної н уки. - 2007. № 8. - . .5-11.

9. онцепція екологічного нормув ння допустимого нтропогенного н в нТ ження н грунтовий покрив // [з ред. . . люк , . . ом щенк ]. - . : гр рн н ук , 2004. -34 c.

10. онцепція інтегров ного упр вління екологічним ризиком дегр д ції грунтів / [з ред. . . люк , . . ом щенк ]. - ., 2012. - 49 с.

\author{
m ття:н дійшл до ред кції 12.03.2013 \\ доопр иьов н 16.04.2013 \\ прийнят до друку 17.06.2013
}

\title{
TRANSFORMATION OF PROPERTIES OF CHORNOZEMS AND THEIR RESISTANCE TO ANTHROPOGENIC PRESSURE
}

\author{
Sviatoslav Baluk, Liudmyla Vorotyntseva \\ The National Science Center \\ "Institute for Soil Science and Agricultural Chemistry named after A. N. Sokolovsky", \\ Chaikovskiy St., 4, UA - 61024, Kharkiv, Ukraine
}

The directions of the transformation of the properties of chernozems under the influence of agricultural use and irrigation are shown. For balanced and sustainable land use is required anthropogenic load on the soil based on the definition of acceptable environmental risk of degradation, taking into account the soil stability to anthropogenic pressure.

Keywords: soil properties, soil, humus, irrigation, soil stability, black soil. 


\section{вятосл в люк， юдмил оротынцев}

цион льный н учный центр “ нститут почвоведения и грохимии имени . . околовского”, ул. йковск я, 4, 61024, г. рьков, кр ин

скрыто н пр вления тр нсформ ции свойств черноземных почв под влиянием сельскохозяйственного использов ния и орошения. ок з но, что для сб л нсиров нного и устойчивого землепользов ния необходим регл мент ция нтропогенной н грузки н почвы н основе определения приемлемого экологического риск их дегр д ции с учетом устойчивости почвы к нтропогенной н грузке.

лючевые слов : свойств почвы, почв , гумус, орошение, устойчивость почвы, черноземные почвы. 